\title{
The Adoption of Temperate Selected Sesame Accessions in the Tropics: Selected for Japan and Grown in Ghana
}

\author{
Kwame D. Ansah ${ }^{1}$, Henry O. Sintim ${ }^{1}$, Samuel Awuah ${ }^{1}$, Joseph E. Ali ${ }^{1} \&$ George Oteng ${ }^{1}$ \\ ${ }^{1}$ Department of General Agriculture, School of Applied Science \& Technology, Sunyani Polytechnic, Sunyani, \\ Ghana \\ Correspondence: Henry O. Sintim, Department of General Agriculture, School of Applied Science \& \\ Technology, Sunyani Polytechnic, P.O. Box 206, Sunyani, Ghana. E-mail: hosintim@gmail.com
}

Received: January 12, 2015 Accepted: February 27, 2015 Online Published: April 15, 2015

doi:10.5539/jas.v7n5p47 URL: http://dx.doi.org/10.5539/jas.v7n5p47

\begin{abstract}
Sesame is an oilseed crop which can be grown on marginal lands. Selection of stable sesame cultivars that can adapt to local environmental conditions can be a very important food security strategy. A set of 21 high yielding sesame accessions that have been selected for a temperate region were grown in the transitional zone of Ghana during the major season of 2014. The seeds were sown after the first rain in the year in a completely randomized design, with three replications. The objective was to evaluate the effect of the contrasting environment on sesame phenology and to select cultivars with yield potential that can be accepted into local farming systems in the new environment. Morphological, physiological and agronomic traits, leading to yield were recorded in this study. Number of capsules per plant had the strongest association (72\%) with seed yield. Five accessions showed a combination of early maturity $<12$ weeks with high overall mean seed yield $(>20$ g per plant $)$ and good harvest index (0.29). Based on their mean performance these cultivars have been selected as promising exotic cultivars for the new locality.
\end{abstract}

Keywords: sesame, climate adaptability, cultivar selection

\section{Introduction}

Sesame (Sesamum indicum L.) is one of the world's oldest spice and oilseed crop grown mainly for its seeds (Morris, 2002; Dorothea, 2003; Francis, 2013). The leading world producers are India, China, Mexico, Myanmar and Sudan in Africa. Sesame seeds are unusually high in oil, around $50 \%$ of the seed weight and $25 \%$ protein, compared to $20 \%$ seed oil for example in soybeans.

Sesame are those tiny seeds which is most familiar as a topping for hamburger bread buns. It is an annual self-pollinating plant with an erect pubescent and sometimes branching stem. It is between 0.6 to $1.3 \mathrm{~m}$ tall. One flower is produced at each leaf axil and the lower flowers usually bloom 2 to 3 months after planting and continue to bloom until the terminal flowers are opened. The world production is estimated at 3.66 million tons with Asia and Africa producing 2.55 and 0.95 million tons respectively. The crop requires only 500-650 mm of rainfall per annum but it could be sensitive to drought during its vegetative stage (Boureima et al., 2011).

As an arable crop, sesame can be grown without irrigation or amended soil nutrition. It is considered drought tolerant, but needs good soil moisture to get established (Myers, 2002). It has a natural pest suppression mechanism (Sintim et al., 2014), can thrive on marginal soils and can be planted three times a year on the same land (Sintim: personal communication). This early or late planting window compares to no other oilseed crop. These attributes make sesame an excellent candidate for inclusion into low-input sustainable food systems.

The total annual consumption is about $65 \%$ for oil extraction and 35\% for food (RMRDC Survey, 2004). It is used in baking, and has edible oil extracted from the seed (Obiajunwa et al., 2005). The oil carries a premium relative to other cooking oils and is considered more stable due to the presence of some antioxidants (Bedigian \& Harlan, 1986; Yoshida \& Kajimoto, 1994; Moazzami et al., 2007; Adebowale et al., 2011). After the oil is extracted from the seed, the remnant cake is high in protein and suitable for feedstock (Jefferson Agricultural Institute, 2003). Although for now sesame oil is used almost exclusively for human food consumption, it has potential for a variety of industrial uses. Sesame plants have also been used to successfully remove organochlorine pesticides from soils (Abhilash \& Singh, 2010). 
Despite the improved potential for increasing the production and productivity of sesame, there are a number of challenges. Over seven million hectares were grown worldwide in 2010, which produced about four million tons of seeds (FAO, 2012). The average world yield is still low at 0.52 ton $^{-1} a^{-1}$ FAO, 2012) which is from low-yielding dehiscent varieties with poor harvest index values, and have significant yield loss during threshing (Ashri, 1998; Uzun \& Cagirgam, 2006). Among these production constraints, the most crucial include the lack of improved cultivars which are high yielding, non-dehiscent and also reliable seed supply (Pham et al., 2010; Tiwari et al., 2011). The average grain yield per hectare has been reported to be relatively low in most producing countries; between 300-350 kg/ha (Phillip, 1977; Saha \& Bhargava, 1980; Schilling \& Cattan, 1991). The fruit capsules dehisce along the suture lines and release the seeds to the ground. These wild characters prevent mechanized harvesting and the expansion of sesame cultivation (Uzun et al., 2003). However, non- dehiscent sesame varieties with yield potential of over 1 ton $\mathrm{ha}^{-1}$ and suitable for mechanical harvest have been developed in the last decade (Langham et al., 2008) confirming the status of sesame as a viable cash crop with tremendous export potential (Oplinger et al., 1990).

Sesame is however catching attention because breeding programs for about 80 years has seen a breakthrough (Anwar et al., 2012) where the crop's major drawback, brittle seed capsules has been solved. The main reason for this delayed success in breeding programs was that it is mainly produced in developing countries and usually by smallholders (Ashri, 2007). For now collections of improved sesame species and cultivars are available in the USA, India, Russia, China, Kenya, South Korea and to a lesser extent Japan, and these provide a valuable gene pool. Ashri (2007) has indicated that, introduced sesame varieties can adapt to new environments within 2-3 seasons of replant. Cultivars to be adopted should be selected based on the local climate, resistance to local pests, and intended use (Sheahan, 2014). Although there is ample evidence indicating that sesame yield depends on the interaction of different climatic parameters such as solar radiation, temperature and humidity (Beech, 1985; Nath et al., 2001) we still had the chance to grow temperate selected sesame cultivars in a tropical area to evaluate its adaptability and yield potential.

\section{Materials and Methods}

\subsection{Location and Plant Materials}

Twenty-one sesame accessions (Table 1) were collected from the sesame bank of University of Toyama, Japan and the pericarp size was classified as: medium, big or large with the large being the size found on bread buns were grown under field conditions after the first rain in March 2014 at Sunyani. Sunyani lies $7.3333^{\circ} \mathrm{N}$, $2.3333^{\circ} \mathrm{W}$ in a tropical forest-savanna transitional zone with a bi-modal annual rainfall. The field experiment was carried out at the research fields of Sunyani Polytechnic, where the annual temperature fluctuates between $25^{\circ} \mathrm{C}$ and $35^{\circ} \mathrm{C}$.

\subsection{Experimental Procedures}

The cultivars were sown in $6 \mathrm{~m}$ long cultivar-alternating plots which were $100 \mathrm{~cm}$ apart with an interplant distance of $40 \mathrm{~cm}$. This was replicated in each of the three blocks. After 2 weeks of growth, plants were thinned to 2 plants per stand and data collection was initiated. Ten mid-row plants of each cultivar per block were randomly tagged as target data subjects.

\subsection{Data Collection}

Plant height from the base to the terminal leaves; stem height from the base to first capsule; fruiting zone length which was the height between the first basal and terminal capsules were each measured using a graduated wooden measure. The number of branches of five randomly selected tagged plants was counted. The number of capsules per plant from each of the five randomly tagged plants was taken. Plants were each cut at the base and the wet biomass yield/plant was determined (leaves, stem, capsules). Fresh capsule weight from ten plants, seed yield per plant, seeds/capsule, and 1000 seed weight were determined using an electronic balance. Harvest Index was taken as the ratio of seed yield to biomass yield per plant.

\subsection{Data Analysis}

Analysis of variance was carried out on above mentioned traits using $9^{\text {th }}$ edition of Genstat ${ }^{\circledR}$ (Release 9.2, 2007). Means of treatments were separated using Least Significant Difference (LSD) after Analysis of Variance (ANOVA) in common probability levels. 
Table 1. Description of 21 sesame accessions used in the study

\begin{tabular}{llll}
\hline No. & Accession & Pericarp colour & Pericarp size \\
\hline 1 & 965 & White & big \\
2 & 565 & White & medium \\
3 & 506 & Tan & large \\
4 & 5951 & White & large \\
5 & 999004 & White & medium \\
6 & 987 & White & medium \\
7 & 5041 & Black & large \\
8 & 958 & Tan & large \\
9 & 6197 & White & large \\
10 & 5183 & Black & large \\
11 & Sudan white & White & large \\
12 & Sudan white (sesamin rich) & White & big \\
13 & 5261 & Black & medium \\
14 & 6295 & Tan & big \\
15 & 9891 & White & big \\
16 & 605 & White & big \\
17 & 52621 & Beige & medium \\
18 & 603 & Tan & big \\
19 & 5391 & White & medium \\
20 & 6071 & White & medium \\
21 & 5762 & khaki & large \\
\hline
\end{tabular}

Note. These accessions were collected from the sesame bank of University of Toyama, Japan.

*Pericarp size was classified as: medium big or large. Large being the normal size found on commercial buns.

\section{Results and Discussion}

All the tested sesame varieties had seed colours and $\mathrm{a} \approx 12$ week maturity period which were true to type as described by the seed breeder or collector. The pericarp sizes were classified to be medium, big or large. The large seed (Table 1) is in reference to commercial seeds used in the bakery industry.

Results obtained from the 21 varieties indicate that there exist wide variations among the varieties. The distance from the first capsule down to the base of the plant was between $22-80 \mathrm{~cm}$ (Table 2) and was significant $(\mathrm{p}<$ $0.001)$. There was a positive correlation $(65 \%)$ between the first capsule height from the base and plant height. The tallest variety (5762) measuring $149 \mathrm{~cm}$ and the shortest variety (603) measuring $112 \mathrm{~cm}$ tall had the first capsule being $63 \mathrm{~cm}$ and $28 \mathrm{~cm}$ above ground respectively. There was a significant difference $(\mathrm{p}<0.02)$ among the plant heights of the varieties. Plant height had a $52 \%$ correlation with yield.

The highly branched varieties, with greater than 15 branches per plant (Table 2); as compared to the no branching types could attain a higher fruiting zone length if the branches were considered. Fruiting zone in this experiment was restricted to the main stem leading to plant height. Branching is very variable in sesame and for these varieties was significant $(\mathrm{p}<0.001$, Table 2$)$.

Fruiting zone which for sesame is the distance between the first basal capsule and the terminal capsule was significant among the varieties $(\mathrm{p}<0.001)$. The mean fruiting zone length was $87 \mathrm{~cm}$. Results from these varieties indicate that fruiting zone length had a negative correlation $36 \%$ with yield. This was especially manifested in the variety (987) with a high above average fruiting zone length of $105 \mathrm{~cm}$ producing a seed yield of $13 \mathrm{~g} /$ plant. This was in contrast with some varieties e.g. (965) with seed yield $29 \mathrm{~g} / \mathrm{plant}$ from a fruiting zone of $85 \mathrm{~cm}$. Yield per plant as a consequent was highly significantly different $(\mathrm{p}<0.001$, Table 4$)$. 
Table 2. Agronomic parameters of sesame cultivars

\begin{tabular}{|c|c|c|c|c|c|}
\hline No. & Accession & $\begin{array}{l}\text { Stem height from base } \\
\text { to the first capsule }[\mathrm{cm}]\end{array}$ & $\begin{array}{l}\text { Plant height } \\
{[\mathrm{cm}]}\end{array}$ & $\begin{array}{l}\text { Fruiting zone } \\
\text { length }[\mathrm{cm}]^{*}\end{array}$ & $\begin{array}{l}\text { Number of } \\
\text { branches }\end{array}$ \\
\hline 1 & 965 & 44.0 & 129.0 & 85.0 & 1.0 \\
\hline 2 & 565 & 35.1 & 142.3 & 107.2 & 1.7 \\
\hline 3 & 506 & 36.4 & 114.4 & 78.0 & 1.3 \\
\hline 4 & 5951 & 32.4 & 138.7 & 106.3 & 1.0 \\
\hline 5 & 999004 & 79.9 & 141.5 & 61.6 & 17.7 \\
\hline 6 & 987 & 29.5 & 133.9 & 104.4 & 0.3 \\
\hline 7 & 5041 & 28.7 & 133.7 & 105.0 & 0.7 \\
\hline 8 & 958 & 28.9 & 117.1 & 88.2 & 0.3 \\
\hline 9 & 6197 & 22.0 & 112.4 & 90.4 & 0.6 \\
\hline 10 & 5183 & 23.9 & 117.4 & 93.5 & 2.3 \\
\hline 11 & Sudan white & 58.9 & 141.2 & 82.3 & 8.3 \\
\hline 12 & Sudan white (sesamin rich) & 54.7 & 125.1 & 70.4 & 9.3 \\
\hline 13 & 5261 & 72.4 & 147.0 & 74.6 & 14.7 \\
\hline 14 & 6295 & 30.9 & 118.6 & 87.7 & 1.3 \\
\hline 15 & 9891 & 31.7 & 128.8 & 97.1 & 0 \\
\hline 16 & 605 & 32.9 & 120.9 & 88.0 & 0 \\
\hline 17 & 52621 & 26.7 & 114.7 & 88.0 & 0.3 \\
\hline 18 & 603 & 27.7 & 111.8 & 84.1 & 0.3 \\
\hline 19 & 5391 & 71.4 & 130.6 & 59.2 & 14.7 \\
\hline 20 & 6071 & 37.9 & 132.3 & 94.4 & 0.3 \\
\hline \multirow[t]{5}{*}{21} & 5762 & 62.8 & 149.3 & 86.5 & 1.00 \\
\hline & F. pro & $<0.001$ & 0.002 & $<.001$ & $<0.001$ \\
\hline & $\mathrm{CV} \%$ & 16.7 & 9.4 & 13.7 & 51.7 \\
\hline & LSD & 11.4 & 19.9 & 19.7 & 3.3 \\
\hline & Grand mean & 41.4 & 128.6 & 87.2 & 3.8 \\
\hline
\end{tabular}

Note. *Fruiting zone length was the height between the first basal and the terminal capsules.

There was no significant difference ( $p=0.29)$ among the varieties in the wet biomass yield (mean $=243 \mathrm{~g} / \mathrm{plant}$ ) although variety (999004) which is highly branched (17/plant) had a wet biomass yield of $454 \mathrm{~g} /$ plant. All other forage or fresh vegetable uses of the sesame varieties were significantly different (Table 3 ). The fresh capsule weight of the variety (9891), $2 \mathrm{~g}$, was above the collection average of $1.4 \mathrm{~g}$.

The 21 varieties had a mean harvest index/plant of 0.48 which was significant $(\mathrm{p}<0.001)$. Variety $(999004)$ also combined a low harvest index (0.29: Table 3 ) and a high wet biomass with good yield of $23 \mathrm{~g} / \mathrm{plant}$. Capsule numbers per plant of these varieties was the best index to predict yield ( $73 \%$ correlation: Table 4$)$. 
Table 3. Forage-use indices of the tested cultivars

\begin{tabular}{|c|c|c|c|c|c|}
\hline No & Accession & $\begin{array}{l}\text { Fresh capsule } \\
\text { weight }(\mathrm{g})\end{array}$ & $\begin{array}{l}\text { Fresh capsule } \\
\text { weight/plant }(\mathrm{g})\end{array}$ & $\begin{array}{l}\text { Wet Biomass } \\
\text { yield/plant (g) }\end{array}$ & $\begin{array}{l}\text { Harvest } \\
\text { index/plant }\end{array}$ \\
\hline 1 & 965 & 1.380 & 155.4 & 317 & 0.5067 \\
\hline 2 & 565 & 1.170 & 89.3 & 179 & 0.4800 \\
\hline 3 & 506 & 1.403 & 110.8 & 182 & 0.5333 \\
\hline 4 & 5951 & 1.253 & 88.1 & 182 & 0.4867 \\
\hline 5 & 999004 & 1.177 & 126.6 & 454 & 0.2900 \\
\hline 6 & 987 & 1.560 & 87.8 & 158 & 0.5667 \\
\hline 7 & 5041 & 1.270 & 95.7 & 180 & 0.5167 \\
\hline 8 & 958 & 1.367 & 86.4 & 168 & 0.5133 \\
\hline 9 & 6197 & 1.423 & 73.7 & 121 & 0.6767 \\
\hline 10 & 5183 & 1.077 & 82.6 & 173 & 0.4867 \\
\hline 11 & Sudan white & 1.320 & 105.8 & 310 & 0.3600 \\
\hline 12 & Sudan white (sesamin rich) & 1.347 & 87.2 & 264 & 0.3433 \\
\hline 13 & 5261 & 1.057 & 84.0 & 768 & 0.3567 \\
\hline 14 & 6295 & 1.287 & 53.0 & 112 & 0.4733 \\
\hline 15 & 9891 & 2.007 & 98.2 & 166 & 0.5400 \\
\hline 16 & 605 & 1.490 & 72.3 & 142 & 0.5233 \\
\hline 17 & 52621 & 1.287 & 59.3 & 115 & 0.5233 \\
\hline 18 & 603 & 1.197 & 88.5 & 146 & 0.5167 \\
\hline 19 & 5391 & 1.503 & 203.8 & 475 & 0.4467 \\
\hline 20 & 6071 & 1.183 & 77.0 & 149 & 0.5233 \\
\hline \multirow[t]{5}{*}{21} & 5762 & 1.287 & 123.0 & 335 & 0.3700 \\
\hline & F. pro & $<0.001$ & 0.004 & 0.29 & $<0.001$ \\
\hline & $\mathrm{CV} \%$ & 9.90 & 36.5 & 102.9 & 12.80 \\
\hline & LSD & 0.2185 & 58.7 & 412 & 0.1008 \\
\hline & Grand mean & 1.335 & 97.5 & 243 & 0.4778 \\
\hline
\end{tabular}

*Wet biomass yield was the fresh weight of leaves, stem and capsules on a plant. Harvest Index was taken as the ratio of seed yield to biomass yield.

The yield of any crop is a very complex quantitative character resulting from different factors, the more important of them being the yield per plant and number of plants per unit area (Menon, 1967). Although sesame has numerous varieties and ecotypes adapted to various ecological conditions (Nzikou et al., 2009; Adebowale et al., 2011) in the present study, we investigated the adaptability of temperate selected varieties in a tropical region. The tested sesame varieties had all the commercial seed colours between white and black. Seed colour is a major trait that affects consumer's acceptability. Paltak and Dixit (1992) reported that the consumer's preference for seed colour differs from region to region for which we need to confirm in Ghana. White sesame seeds, have higher oil, protein and moisture ratios as compared to black seeded sesame (Kanu, 2011). The physical appearance is a key marketing indicator and acceptability of sesame type varies greatly with cultural preferences. The Sudanese favour white seeded sesame whilst the Japanese prefer black seeded ones (Hossain et al., 2010). In particular, a larger seed size, coupled with a light-coloured seed coat like white, often command price premiums in a market-dependent manner (Cassells \& Caddick, 2000; Graham et al., 2001). In parts of Asia for example, white seeded sesame sells at least 30\% higher than dark coloured varieties (Chakraborty et al., 1984). 
Table 4. Seed and capsule yield of sesame cultivars

\begin{tabular}{|c|c|c|c|c|c|}
\hline No. & Accession & $\begin{array}{l}\text { Number of capsules } \\
\text { per plant }\end{array}$ & $\begin{array}{l}\text { Number of seeds } \\
\text { per capsule }\end{array}$ & $\begin{array}{l}\text { Seed yield } \\
\text { per plant }(\mathrm{g})\end{array}$ & $\begin{array}{r}1000 \text {-seed } \\
\text { weight }(\mathrm{g})\end{array}$ \\
\hline 1 & 965 & 134.3 & 67.8 & 28.85 & 3.400 \\
\hline 2 & 565 & 97.7 & 94.0 & 22.86 & 2.833 \\
\hline 3 & 506 & 96.3 & 50.3 & 17.53 & 3.000 \\
\hline 4 & 5951 & 111.7 & 53.3 & 17.80 & 3.467 \\
\hline 5 & 999004 & 161.3 & 56.0 & 22.63 & 4.233 \\
\hline 6 & 987 & 66.7 & 55.3 & 12.58 & 3.267 \\
\hline 7 & 5041 & 134.3 & 83.7 & 17.69 & 2.533 \\
\hline 8 & 958 & 78.0 & 80.7 & 13.62 & 2.800 \\
\hline 9 & 6197 & 56.7 & 54.0 & 13.36 & 3.200 \\
\hline 10 & 5183 & 81.0 & 81.0 & 19.21 & 3.167 \\
\hline 11 & Sudan white & 60.0 & 60.0 & 19.02 & 3.833 \\
\hline 12 & Sudan white (sesamin rich) & 60.3 & 60.3 & 15.71 & 3.700 \\
\hline 13 & 5261 & 52.7 & 52.7 & 18.89 & 3.200 \\
\hline 14 & 6295 & 62.7 & 62.7 & 10.55 & 2.733 \\
\hline 15 & 9891 & 64.0 & 64.0 & 14.64 & 3.667 \\
\hline 16 & 605 & 57.7 & 57.7 & 13.10 & 2.967 \\
\hline 17 & 52621 & 82.0 & 43.0 & 11.76 & 3.133 \\
\hline 18 & 603 & 82.0 & 66.0 & 12.29 & 2.767 \\
\hline 19 & 5391 & 162.7 & 58.0 & 29.75 & 3.167 \\
\hline 20 & 6071 & 87.7 & 51.0 & 15.97 & 2.833 \\
\hline \multirow[t]{5}{*}{21} & 5762 & 96.0 & 72.7 & 22.10 & 3.400 \\
\hline & F. pro & 0.007 & 0.020 & $<0.001$ & $<0.001$ \\
\hline & CV\% & 34.4 & 23.1 & 29.40 & 9.80 \\
\hline & LSD & 55.0 & 9.21 & 8.534 & 0.5204 \\
\hline & Grand mean & 97.0 & 62.70 & 17.62 & 3.205 \\
\hline
\end{tabular}

Plant density is a crucial index in sesame and an optimum of 400,000 plants/ha has been recommended (Katung, 2003). In earlier experiments in Ghana, Sintim and Yeboah Badu (2010) at 250,000 plants/ha obtained yields that were above quoted yield values in Africa. Seed yield is a complex trait governed by polygenes and therefore is influenced more by environmental factors (Basu et al., 2009). Another important factor that influences the seed yield of sesame is varietal differences hence the need to select varieties of good quality that can be adjusted to the local climatic conditions (Pham et al., 2010). In other sesame growing areas in the tropics, seed yield of $37 \mathrm{~g}$ per plant has been reported in controlled pollinated fields. The tested varieties with greater that $20 \mathrm{~g}$ seed yield per plant are very promising and will be introduced into the local farming/cropping system. Although characters such as plant height of determinate varieties (Uzun \& Cagirgan, 2001) and early maturation (Day, 2000; Day et al., 2002) make a great contribution to seed yield these attributes are variety specific. The most crucial index should rather relate to internode length and capsules per node. In the varieties tested, plant height and fruiting zone length were not a critical determinant of yield. Plants with tall stems should combine with short length of basal capsule from the ground, short internode and number of capsules per internode to ensure high yield. Early maturation is very important where sesame is grown as a second crop in areas with short seasons. Currently we have been able to grow sesame in a three season cycle in a year if we utilize the first rain in early March for our 12 week maturity sesame varieties. The selection of varieties should however not sacrifice plant features related to earliness for only seed yield. There have been instances where seed yield was negatively correlated with plant height (Ngala et al., 2013) which is similar to results from this experiment. In our case it was attributed to long 
internodes and low capsule number per node for some varieties.

Sesame has shown in other places to be highly sensitive to day length (Narayanan \& Reddy, 1982; Suddihiyam et al., 1992) and has significant interactions with temperature (Suddihiyam et al., 1992). Oil content has been found to be influenced negatively by temperature (Kamal-Eldin \& Appelqvist, 1994). It flowers in about 45 days under 10-hour day length. The short day length requirement was not considered to be crucial for these varieties, since summer day length is even longer in temperate regions from where the seeds were collected. Sesame is also reported to adapt to different photoperiod requirements (Ashri, 2007) as well as the existence of day-neutral cultivars. These new temperate selected varieties can fit into our cropping pattern as most of the land is normally fallow after harvesting a main crop due to the long term moisture requirements for native crops. Sesame is also known to be a good candidate when planted as a primary crop or a secondary crop after wheat (Langham et al., 2008). The performance of these adaptable varieties such as: those with more than 100 capsules per plant, 90 seeds per capsule, $4.23 \mathrm{~g} \mathrm{1000-seed} \mathrm{weight} \mathrm{are} \mathrm{comparable} \mathrm{to} \mathrm{the} \mathrm{high} \mathrm{yield} \mathrm{value} \mathrm{of} 3.59 \mathrm{~g} 1000$-seed weight reported elsewhere for high yielding varieties by Anwar et al. (2012) and Hassan (2012).

\section{Conclusions}

For other attributes not tested in this experiment: sesame can increase yields in subsequent cash crops by successfully improving soil moisture retention and soil texture. It is notable for its ability to grow under droughty conditions and in extreme heat and under conditions where few other crops can survive as it requires very few inputs. These attributes make sesame an excellent candidate for low-input sustainable food systems as required in Ghana.

\section{References}

Abhilash, P. C., \& Singh, N. (2010). Effect of growing Sesamum indicum L. on enhanced dissipation of lindane (1,2,3,4,5, 6-hexachlorocyclohexane) from soil. International Journal of Phytoremediation, 12, 440-453. http://dx.doi.org/10.1080/1522651090321394

Adebowale, A. A., Sanni, S. A., \& Falore, O. A. (2011). Varietal differences in the physical properties and proximate composition of elite sesame seeds. World Journal of Agricultural Sciences, 7, 42-46.

Anwar, M., Hasan, E.-U., Mahmood, T., Iqbal, J., \& Hussain, M. (2012). TS-5: A new high yielding sesame cultivar. Journal of Agricultural Research, 50, 477-484.

Ashri, A. (1998). Sesame breeding. Plant Breeding Reviews, 16, 179-228. http://dx.doi.org/10.1002/9780470650110

Ashri, A. (2007). Sesame (Sesamum indicum L.). In R. J. Singh (Eds.), Genetic Resources, Chromosome Engineering, and Crop Improvement (Vol. 4, pp. 231-289, Oilseed Crops). Boca Raton, FL, USA: CRC Press.

Basu, S. K., Acharya, S. N., Bandara, M. S., Friebel, D., \& Thomas, J. E. (2009). Effects of genotype and environment on seed and forage yield in fenugreek (Trigonella foenum-graecum L.) grown in Western Canada. Australian Journal of Crop Science, 3, 305-314. Retrieved from http://www.cropj.com/saikat_3_6_2009_305_314.pdf

Bedigian, D., \& Harlan, J. (1986). Evidence for cultivation of sesame in the ancient world. Economic Botany, 40, 137-154.

Beech, D. (1985). Sesame research possibilities for yield improvement. In A. Ashri (Eds.), Sesame and safflower: Status and potential (pp. 121-126). FAO plant production and protection, Rome. Retrieved from http://safflower.wsu.edu/newsletter1985.pdf

Boureima, S., Eyletters, M., Diouf, M., Diop, T. A., \& Van Damme, P. (2011). Sensitivity of seed germination and seedling radicle growth to drought stress in sesame (Sesamum indicum L.). Research Journal of Environmental Sciences, 5, 557-564. http://dx.doi.org/10.3923/rjes.2011.557.564

Cassells, J., \& Caddick, L. (2000). Harvest timing critical for chickpea quality. Farming Ahead, 107, 41-42.

Chakraborty, P. K., Maiti, S., \& Chatterjee, B. N. (1984). Growth analysis and agronomic appraisal of Sesamum indicum L. Indian Journal of Agricultural Science, 54, 291-295.

Day, J. S. (2000). Development and maturation of sesame seeds and capsules. Field Crops Research, 67, 1-9. http://dx.doi.org/10.1016/S0378-4290(00)00073-3

Day, J. S., Langham, D. R., \& Wongyai, W. (2002). Potential selection criteria for the development of high-yielding determinate sesame varieties. Sesame Safflower Newsletter, 17, 29-35. 
Dorothea, B. (2003). Evolution of sesame revisited: domestication, diversity and prospects. Genetic Resources and Crop Evolution, 50, 779-787. http://dx.doi.org/10.1023/A:1025029903549

FAO. (2012). FAOSTAT Databases. Retrieved from http://www.faostat.fao.org

Francis, E. (2013). Sesame: For the Cooperative Extension Service University of Arkansas System Division of Agriculture.

Genstat ${ }^{\circledR}$ Release 9.2. (2007). Lawes Agricultural Trust. Rothamted Experimental Station.

Graham, J., Matassa, V., Panozzo, J., \& Starick, N. (2001). Genotype and environment interaction for whole grain colour in chickpea (pp. 372-373). $4^{\text {th }}$ European Conference on Grain Legumes.

Hassan, M. A. M. (2012). Studies on Egyptian sesame seeds (Sesamum indicum L.) and its products 1-physicochemical analysis and phenolic acids of roasted Egyptian sesame seeds (Sesamum indicum L.). World Journal of Dairy \& Food Sciences, 7, 195-201.

Hossain, S., Ford, R., McNeil, D., Pittock, C., \& Pannozo, J. F. (2010). Inheritance of seed size in chickpea (Cicer arietinum L.) and identification of QTL based on 100-seed weight and seed size index. Australian Journal of Crop Science, 4, 126-135.

Jefferson Agricultural Institute. (2003). Strategies for Commercializing New Crops (Report of a Workshop). St. Louis, Missouri Thomas Jefferson Agricultural Institute. Retrieved from http://www.jerfersoninstitute.org

Kamal-Eldin, A., \& Appelqvist, L. A. (1994). Variation in fatty acid composition of the different acyl lipids in seed oils four Sesamum species. Journal of American Oil Chemists' Society, 71, 135-139. http://dx.doi.org/10.1007/BF02541547

Kanu, P. J. (2011). Biochemical analysis of black and white Sesame seeds from China. American Journal of Biochemistry and Molecular Biology, 1, 145-157. http://dx.doi.org/10.3923/ajbmb.2011.145.157

Katung, P. D. (2003). The response of two varieties of sesame (Sesamum indicum, L.) to different plant populations and sowing dates at Samaru, Northern Guinea savanna. Samaru Journal of Agricultural Research, 19, 17-27.

Langham, D. R., Riney, J., Smith, G., \& Wiemers, T. (2008). Sesame grower guide. Sesaco sesame coordinators, Lubbock, TX. Retrieved Decemeber 18, 2014, from http://www.sesaco.net

Menon, E. F. (1967). Effects of varying spacing on yield of sesame. Indian Journal of Agronomy, 12, 274-276.

Moazzami, A. A., Haese, S. L., \& Kamal-Eldin, A. (2007). Lignan contents in sesame seeds and products. European Journal of Lipid Science and Technology, 109, 1022-1027. http://dx.doi.org/10.1002/ejlt.200700057

Morris, J. B. (2002). Food, industrial, nutraceutical, and pharmaceutical uses of sesame genetic resources. In J. Janick \& A. Whipkey (Eds.), Trends in New Crops and New Uses (pp. 153-156). ASHS Press, Alexandria, VA.

Myers, L. R. (2002). Sesame: A high value oilseed. Alternative crop guide Jefferson Institute, Columbia, MO. Retrieved from http://www.jeffersoninstitute.org

Myers, R. (2002). Alternative crop guide: Sesame. Jefferson Institute, Columbia, MO. Retrieved July 15, 2014, from http://www.jeffersoninstitute.org

Narayanan, A., \& Reddy, K. B. (1982). Growth, Development and yield of sesame (Sesamum indicum L.) cultivars. Field Crop Research, 5, 217-224. http://dx.doi.org/10.1016/0378-4290(82)90024-7

Nath, R., Chakraborty, P. K., \& Chakraborty, A. (2001). Effect of climatic variation on yield of sesame (Sesamum indicum L.) at different dates of sowing. Journal of Agronomy and Crop Science, 186, 97-102. http://dx.doi.org/10.1046/j.1439-037X.2001.00456.x

Ngala, A. L., Dugje, I. Y., \& Yakubu, H. (2013). Effects of inter-row spacing and plant density on performance of sesame (Sesamum indicum L.) in a Nigerian Sudan savanna. Science International (Lahore), 25, 513-519. http://dx.doi.org/10.13140/2.1.2230.3368

Nzikou, J. M., Matos, L., Bouanga-Kalou, G., Ndangui, C. B., Pambou-Tobi, N. P. G., Kimbonguila, A., \& Desobry, S. (2009). Chemical composition on the seeds and oil of sesame (Sesamum indicum L.) grown in Congo-Brazzaville. Advance Journal of Food Science and Technology, 1, 6-11.

Obiajunwa, E. I., Adebiyi, F. M., \& Omode, P. E. (2005). Determination of essential minerals and trace elements 
in Nigerian sesame seeds using TXRF technique. Pakistan Journal of Nutrition, 4, 393-395. http://dx.doi.org/10.3923/pjn.2005.393.395

Oplinger, E. S., Punta, D. H., Kaminski, A. R., Hanson, C. V., Oelke, E. A., Schutte, E. E. \& Doll, J. D. (1990). Sesame: Alternative field crop manual. Retrieved from http://www.hort.purdue.edu/newcrop.afcm/sesame. html

Paltak, H. C., \& Dixit, S. K. (1992). Genetic variability and inter-relationship studies in black seeded sesame (Sesamum indicum L.). Madras Agricultural Journal, 79, 4-100.

Pham, T. D., Nguyen, T. T., Carlsson, A. S., \& Bui, T. M. (2010). Morphological evaluation of sesame (Sesamum indicum L.) varieties from different origins. Australian Journal of Crop Science, 4, 498-504. http://dx.doi.org/dn=536481490080115

Phillip, T. A. (1977). Sesame: An agricultural notebook (pp. 61-63). New edition, Longman Group Ltd., London.

Raw Materials Research and Development Council-RMRDC. (2004). Survey report of ten selected agro raw materials in Nigeria. Beniseed (1st ed., p. 108).

Saha, S. N., \& Bhargava, S. C. (1980). Physiological analysis of growth, development and yield of oilseed sesame. Journal of Agricultural Science, 958, 733-736. http://dx.doi.org/10.1017/S0021859600088158

Schilling, R., \& Cattan, P. (1991). Sesame cultivation in tropical Africa. Oleagineux, 46, 129-131.

Sheahan, C. M. (2014). Plant guide for sesame (Sesamum orientale). USDA-Natural Resources Conservation Service, Cape May Plant Materials Center, Cape May, NJ.

Sintim, H. O., \& Yeboah Badu, V. I. (2010). Evaluation of Sesame (Sesamum indicum) production in Ghana. Journal of Animal and Plant Sciences, 6, 653- 662. Retrieved from http://www.biosciences.elewa.org/JAPS

Sintim, H. O., Yeboah Badu, V. I., Akotsen Mensah, C., \& Ansah Duodu, K. (2014). A faunistic description of endemic arthropods associated with sesame. Advances in Natural Science, 7, 1-7. http://dx.doi.org/10.3968\%2F4788

Suddihiyam, P., Steer, B. T., \& Turner, D. W. (1992). The flowering of sesame (Sesamum indicum L.) in response to temperature and photoperiod. Australian Journal of Agricultural Research, 43, 1101-1116. http://dx.doi.org/10.1071/AR9921101

Tiwari, S., Kumar, S., \& Gontia, I. (2011). Biotechnological approaches for sesame (Sesamum indicum L.) and niger (Guizotia abyssinica L. f. Cass.). Asia-Pacific Journal of Molecular Biology and Biotechnology, 19, $2-9$.

Uzun, B., \& Cagirgan, M. I. (2001). Path-coefficient analysis for seed yield and related characters in a population of determinate and indeterminate types of sesame (Sesamum indicum L.). Turkish Journal of Field Crops, 6, 76-80. Retrieved from http://www.field-crops.org/assets/pdf/product51b2ec340cef9.pdf

Uzun, B., \& Cagirgan, M. I. (2006). Comparison of determinate and indeterminate lines of sesame for agronomic traits. Field Crops Research, 96, 13-18. http://dx.doi.org/10.1016/j.fcr.2005.04.017

Uzun, B., Lee, D., Donini, P., \& Cagirgan, M. I. (2003). Identification of an AFLP marker linked to the closed capsule mutant trait in sesame. Plant Breeding, 122, 95-97. http://dx.doi.org/10.1046/j.1439-0523.2003.00787.x

Yoshida, H., \& Kajimoto, M. (1994). Composition and quality characteristics of sesame seed (Sesamum indicum) oil roasted at different temperature in an electric oven. Journal of Food Science, 65, 331-336. http://dx.doi.org/10.1002/jsfa.2740650311

\section{Copyrights}

Copyright for this article is retained by the author(s), with first publication rights granted to the journal.

This is an open-access article distributed under the terms and conditions of the Creative Commons Attribution license (http://creativecommons.org/licenses/by/3.0/). 